\title{
REVIEW OF RISKS REGARDING LOW TAX JURISDICTIONS WITHIN THE ESTONIAN TAX SYSTEM
}

\author{
Andrei Novikov \\ University of Tartu \\ Ülikooli 18, Tartu, Estonia, 50090 \\ Lawyer.dklex@gmail.com
}

\begin{abstract}
Over the last decade a tendency in the world started, regarding an opposition to the use of the offshore jurisdictions. Most of the countries have implemented legal norms, which create obstacles for pulling out capital from the state and into the low tax jurisdiction. As such, in order to do business one must not only understand the tax system of the country itself, but also how it regulates deals with offshores.

Ignoring this matter may lead to unplanned tax losses and damage the reputation of the company. At the same time, knowing such legal norms allow one to plan out his business and create an effective tax optimized business model, that will be able to provide stable income without breaking any legal norms.

In addition, Estonia, due its own tax system and due to being a member of EU provides sufficient grounds for effective tax planning. Thus, the matter of low tax jurisdiction regulation becomes even more important.
\end{abstract}

Keywords: Low tax jurisdiction, Estonia, Tax system, Tax planning.

\section{Problem and used sources}

Low tax jurisdiction have long been used in tax planning, but over the last few years, the legislation allows for less and less opportunities for their use. The present overview shall give a picture of how Estonian legislation regulates such agreements and what opportunities for tax planning exist.

The article is written by the means of clear review of obtained data regarding the problem and found solutions.

\section{Aim of the article}

The present article aims to provide up to date information of the active Estonian legislation regarding transactions with low tax jurisdictions and how extra tax burden can be avoided with such agreements.

Currently it is a surprise for many businessmen when they face extra taxes when dealing with low tax jurisdictions. This article will help the reader see and evaluate the risks and thus avoid entering into an unprofitable agreement.

\section{Used materials}

The main information source for this article is the active legislation of Estonia, in particular Income tax law. Trustworthy information is also provided by Estonian Tax and Customs board and additional the commentaries of known Estonian tax law experts are use.

\section{Estonian tax system and low tax jurisdictions}

The Estonian tax system was created in order to establish a comfortable atmosphere for business. Estonian companies do not pay income tax until they distribute profits as dividends [1, 2], what allows the business to develop effectively without any tax burden.

Also Estonia is a member of EU, which means that it is a part of the European tax regulation, that allows to use intercommunity turnover with a tax rate of $0 \%$ [3], and additionally apply parent subsidiary directive that allows for tax planning within groups of companies.

Despite such significant tax planning possibilities Estonia has good reputation and is not considered a low tax jurisdiction (offshore). But, as most other states Estonian has legal norms that oppose the capital flow outside the country into the offshores. It means that all Estonian companies must have this in mind when they make deals with low tax jurisdictions; as such agreements may be the reason for extra tax burden as will be described below. 
However, before we review examples, we have to make it clear, what companies may be considered low tax under Estonian law.

First of all, article 10 of the income tax law defines low tax jurisdictions as any territory, where the income tax rate is lower than 1/3 of Estonian (currently income tax rate in Estonia is $20 \%$ [4]. Also, any company unable to provide a certificate of residency can be considered to be from low tax jurisdiction, no matter where it is registered [5]. Such a problem may arise when dealing with companies with a corporate form of LP and LLP that exist in common law system.

\section{Risks when dealing with low tax jurisdictions}

Regarding the risks of working with such companies it should first of all be noted, that there is no risk when receiving payment for goods or services from such companies. The tax risk appears when the Estonian company buys goods or services from low tax jurisdictions.

When buying goods an income tax in the amount of $20 \%$ from the value of the transaction must be paid. Nevertheless, the tax system of Estonian allows for the return of that tax once the goods arrive to the destination and that is confirmed with documents. If the payment for the goods after the goods have already arrived the procedure regarding paying the tax and applying for its return can be skipped, should the matter be first settled with the Tax and Customs board with the presentation of the valid documentation proving the arrival of the goods (CMR, bill of lading).

However, if the Estonian company is buying services from the low tax jurisdiction then there is no avoiding the payment of the income tax. [6]. Also in this situation, the paid up tax will never be returned.

\section{Discussion of the article and practical use}

The present article gives a short review of how Estonian legislation regulates deals with low tax jurisdictions. However, the present article only regarded sales-purchase agreements of goods and services.

In the future, other agreements may be reviewed, for example, loan agreements.

\section{Conclusion and practical use}

As such it can be concluded that when an Estonian company buys services from low tax jurisdictions it always leads to an extra tax burden. Should the company buy goods there are options that will allow avoiding the tax burden if the supply of goods did actually happen.

Overall, one must remember the main principle behind the regulation of the agreements with low tax jurisdictions by the Estonian legislation. The main goal is to prevent the capital from leaving the country and to prevent the tax avoidance. Receiving money form low tax jurisdiction does not cause problems, and the Estonian company may sell goods and services there as much as it wants. Also when buying goods the tax burden can be eventually avoided, provided there is documental proof that the deal was real.

Services are by their very nature immaterial, it is far harder to prove that they were actually provided and as such buying services will lead to unavoidable tax burden.

It is clear, that knowing tax norms and how they are applied can help the business owner avoid tax risks. If one has doubts about how his planned agreement will be interpreted and if there will be any unplanned taxes, it is always worth it turn to a lawyer or directly to the tax department.

\section{References}

[1] Article 1 of the Estonian Income Tax Law

[2] Article 50 of the Estonian Income Tax Law

[3] EU 2006 directive 2006/112/EC

[4] Article 10 of the Estonian Income tax law

[5] Commentary of the Estonian Tax and Customs board. Available at: https://www.emta.ee/et/ ariklient/tulud-kulud-kaive-kasum/mitteresidendi-eesti-tulu-maksustamine/nimekiri-territooriumidest

[6] Article 29 part 3 of the Estonian Income Tax Law 